\title{
Potential Economic Losses Due to Tidal Inundation and Flood at Semarang City
}

\author{
Ifan R Suhelmi ${ }^{1}$, Achmad Fahrudin ${ }^{2}$, and Ferdinand Hariyanto Triwibowo ${ }^{2}$ \\ 1) Pusat Penelitian dan Pengembangan Sumberdaya Laut dan Pesisir, Balitbang Kelautan dan Perikanan, J1 Pasir Putih 1 \\ Ancol Timur Jakarta \\ 2) Program Studi Pengelolaan Pesisir dan Lautan, Sekolah Pascasarjana IPB Bogor \\ e-mail:ifan_ridlo@yahoo.com
}

\begin{abstract}
Coastal city of Semarang is susceptible to the impact of coastal hazard due to its flat topographic condition. Various environmental problems are faced by Semarang involve tidal inundation, land subsidence, and floods during rainy season. This study was conducted to examine the potential economic losses caused by the sea level rise phenomenon. Distribution of inundated area mapped using Digital Elevation Model and Land Subsidence data. The Scenarios of International Panel on Climate Change (2007) sea level rises used to build a model of inundated area that notes by 2030 the rise of sea level rise at $13.4 \mathrm{~cm}$. The inundated map was overlayed with landuse map to calculate the potential economic losses. The results show that the inundated area that occurred in 2030 was 1,718.2 ha with the potential economic losses Rp. 6,130 trillion. With the land subsidence scenario that happen at the area, inundated area increased to 5,171.3 ha with the eonomic potential loss about Rp. 28,724 trillion.
\end{abstract}

Keywords: sea level rise, land subsidence, potensial losses

\begin{abstract}
Abstrak
Kondisi topografi Kota Semarang dapat dikelompokkan menjadi dua, yaitu topografi datar dan topografi bergunung. Pada wilayah bertopografi datar rentan terhadap genangan, baik akibat banjir maupun pengaruh kenaikan muka air laut. Penelitian ini dilakukan untuk mengkaji potensi kerugian ekonomi yang ditimbulkan oleh genangan yang disebabkan oleh kenaikan muka air laut dan penurunan tanah. Distribusi genangan akibat kenaikan muka air laut dan penurunan tanah diolah dari DEM dan data penurunan tanah. Besaran kenaikan muka air laut menggunakan skenario IPCC (2007) yang mempredikasikan kenaikan sebesar 13,4 cm pada tahun 2030. Hasil pemetaan distribusi genangan dioverlaykan dengan peta penggunaan lahan saat ini. Perhitungan potensi kerugian ekonomi dilakukan untuk setiap jenis penggunaan lahan. Hasil pemetaan distribusi genangan dioverlaykan dengan peta penggunaan lahan. Perhitungan potensi kerugian ekonomi dilakukan untuk setiap jenis penggunaan lahan. Hasil penelitian menunjukkan bahwa genangan yang terjadi pada tahun 2030 akibat kenaikan muka air laut sebesar 1.718,2 Ha dengan potensi kerugian ekonomi Rp. 6.130 Trilyun. Dengan memperhatikan aspek penurunan tanah, luas genangan menjadi 5.171,3 ha dengan potensi kerugian mencapai Rp. 28.724 Trilyun.
\end{abstract}

Kata kunci: kenaikan muka air laut, penurunan tanah, potensi kerugian

\section{Introduction}

Indonesia, as an archipelago, is very vulnerable to the double impact of the climate changes. Although it is still not estimated yet how the hazardous events are, some significant impacts for sure will appear; the rise of temperature, rain precipitation, sea level, food sovereignty and the impact on variety of sea animals (World Bank, 2009).

Climate change is a natural phenomenon which is difficult to avoid in any aspects of life. The deepest impact of the climate change is the rise of temperature and season change. Climate change is something that we face in some parts of the world; floods, marine tides, and drought. Some coastal cities are considerably vulnerable to the impact of the change. In Indonesia, there are 60 cities which are susceptible to flood and 30 cities which are susceptible to tsunami. Based on the that fact, it is important to prepare mitigation and adaptation efforts for these circumstances (Lubis, 2011).

To estimate the impacts of climate change, there are some different methods developed for this reason. Some approaches are explained as the concept of Disaster Risk Reduction (DRR) dan the approach of climate change (Surminski et. al. 2012).

Semarang as a big coastal city frequently faces various environmental problems and floods are particularly a big threat for this city. Floods can be 
classified into several categories: tidal inundation, local flood and river flood (Suhelmi, 2012)

A river flood deals with the change of land utilization causing the rise of a river to an elevation that the river overflows its natural banks (Suroso dan Susanto 2006; Khasanah et al. 2004). Meanwhile, local flood deals with the city drainage. The heavy rain and the deficient drainage system such as chaotic waste management will lead to the local flood.

To estimate potential economic loss due to tidal inundation, it is needed a comprehensive study with more specific data about the impact of climate change phenomenon and its result will be useful in estimating land utilization planning. Obviously, the aim of this study is to estimate potential economic losses and damages due to tidal inundation as the impact of the climate change particularly the sea level rises.

\section{Research Method}

The areas of potential loss research due to tidal inundation in Semarang city are shown in Figure 1. This research basically is a sequel of physical research about the areas of tidal inundation due to sea level rises. The result of this research, therefore, will be useful to estimate the potential economic losses due to tidal inundations.

Estimation of the tidal inundations due to sea level rises uses IPCC Prediction (2007) in 2030. Prediction of the inundation is analyzed based on the DEM data of the research area using geographical information system.

Prediction of the potential losses due to tidal inundation can be done by calculating the inundation areas per hectare. Land utilization has a correlation with a certain

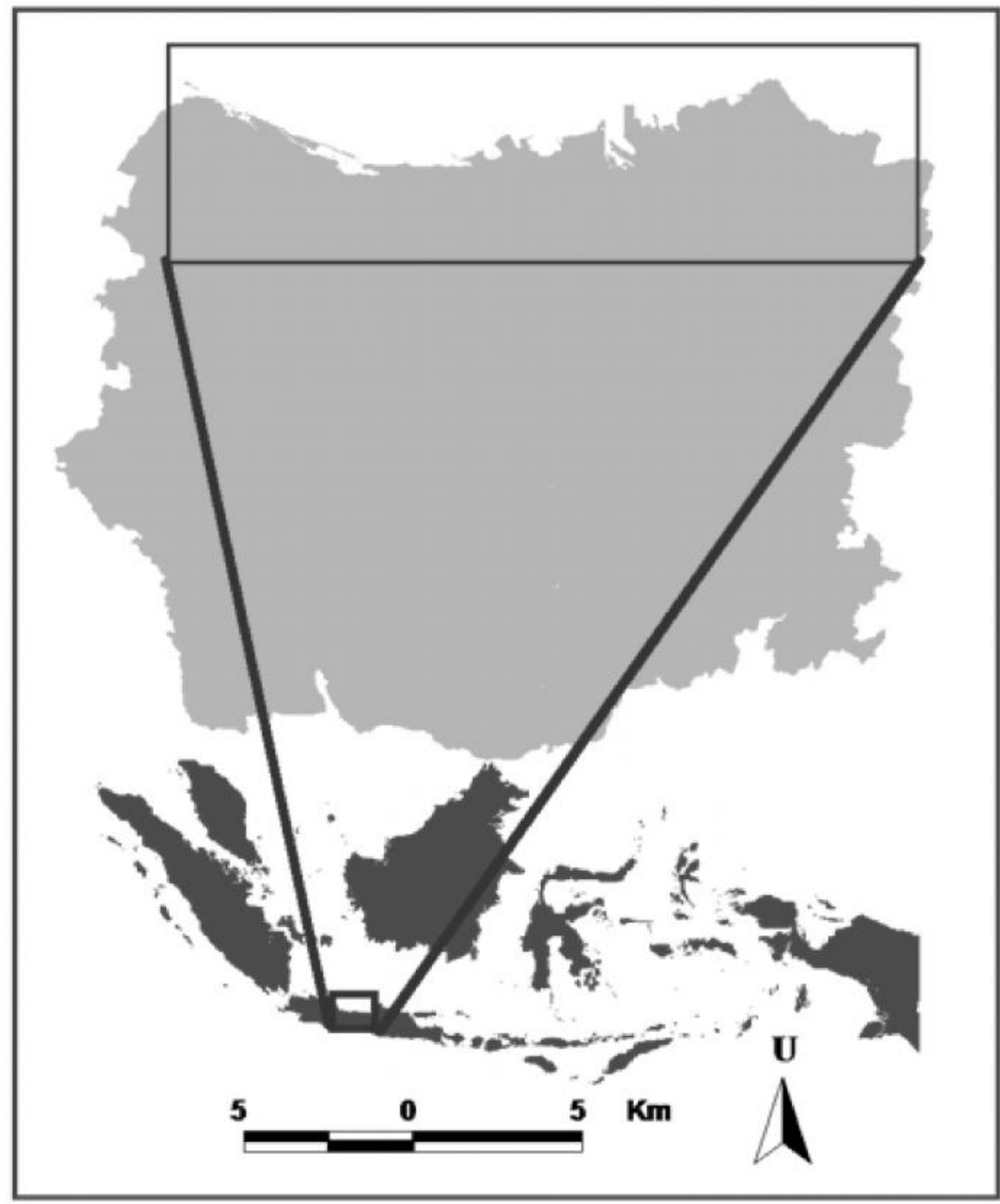

Figure 1. Research Area 
economical value (Ward et al., 2011). Estimation of the loss is calculated by counting the land utilization areas in hectare. There are 2 kinds of residential areas, the regular and irregular pattern. Value estimation of the uniform residential area is 14.7 billion rupiahs ( $€ 1.2$ million) per hectare while it is 12,255 billion rupiahs ( $€ 1$ million) per hectare for other type. The value estimation which is used in this research is for irregular building. Meanwhile, for agriculture, the estimation is about 980 million rupiahs $(€ 80,000)$ per hectare (Marfai dan King, 2008, Ward et al., 2011). Another value from the bussiness areas is 30.6 billion rupiahs( $€ 2.5$ million), from the dikes is 1.16 billion rupiahs $(€ 95,000)$, and from bareland is 20.83 million rupiahs $(€ 1,700)$ (DGME, 2004; Marfai and King, 2008). It is not a market value thatis used in this research, but it is a value-based approach.

\section{Result and Discussion}

Tidal inundation brings some significat impacts to the life in Semarang. Its frequency deals with the condition of the coastal tides. Some types of tidal are discussed in this research. In semi diurnal tide, the area experiences two high and two low tides of approximately equal size every lunar day. Suhelmi (2011) explains that type of tidal in Semarang is the mixed tide prevailing diurnal so that it brings double impacts of inundation.

Figure 2 to Figure 4 show the distribution of tidal inundation on pesimist and optimist scenario in 2030 when the tidal reaches its highest peak whereas Figure 5 and Figure 6 show the condition of the sea level rise in 2030 by considering the 1 and subsidence. Obviously, Figure 2 to Figure 6 are used as a

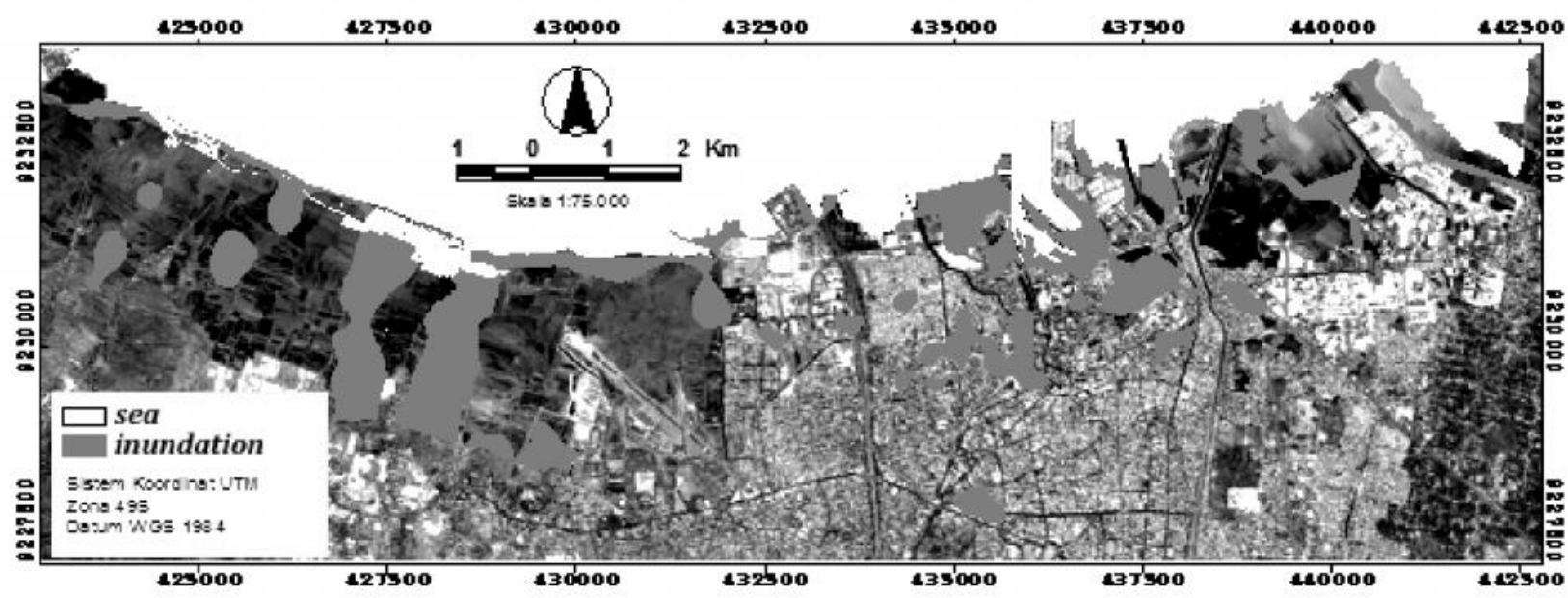

Figure 2. Distribution of tidal inundation to scenario SLR 2010

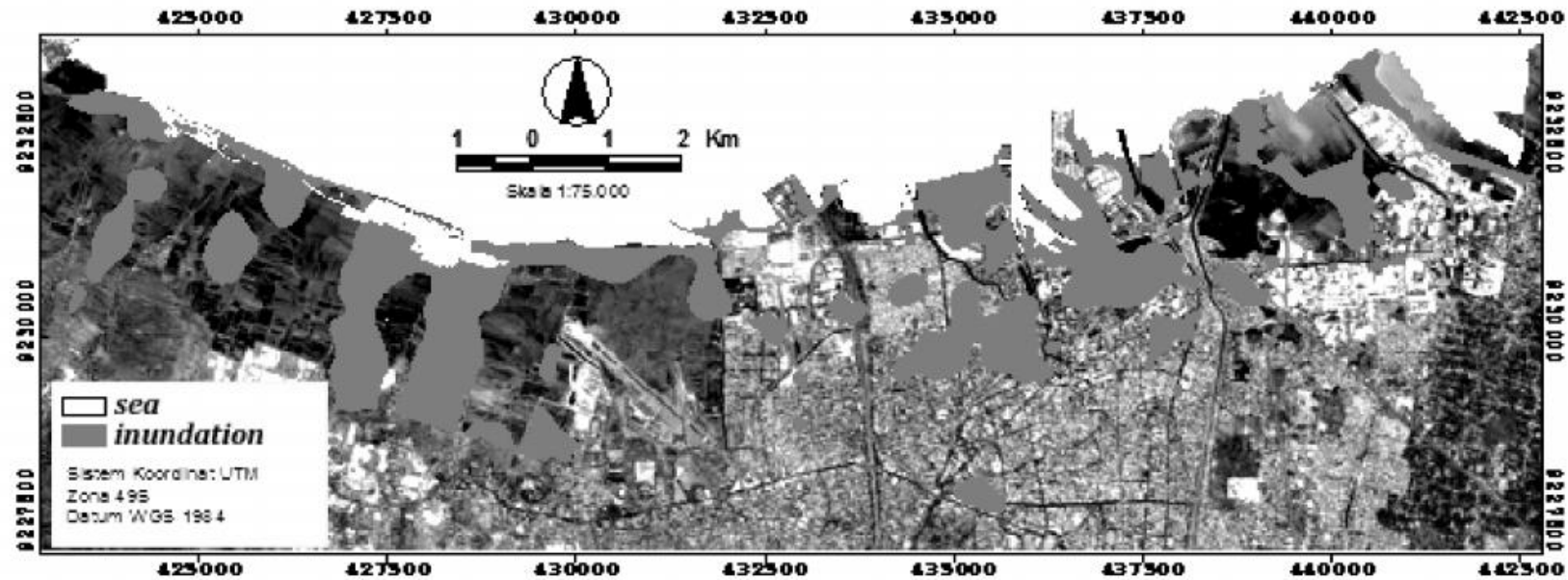

Figure 3. Distribution of inundation to pessimistic scenario SLR 2030 


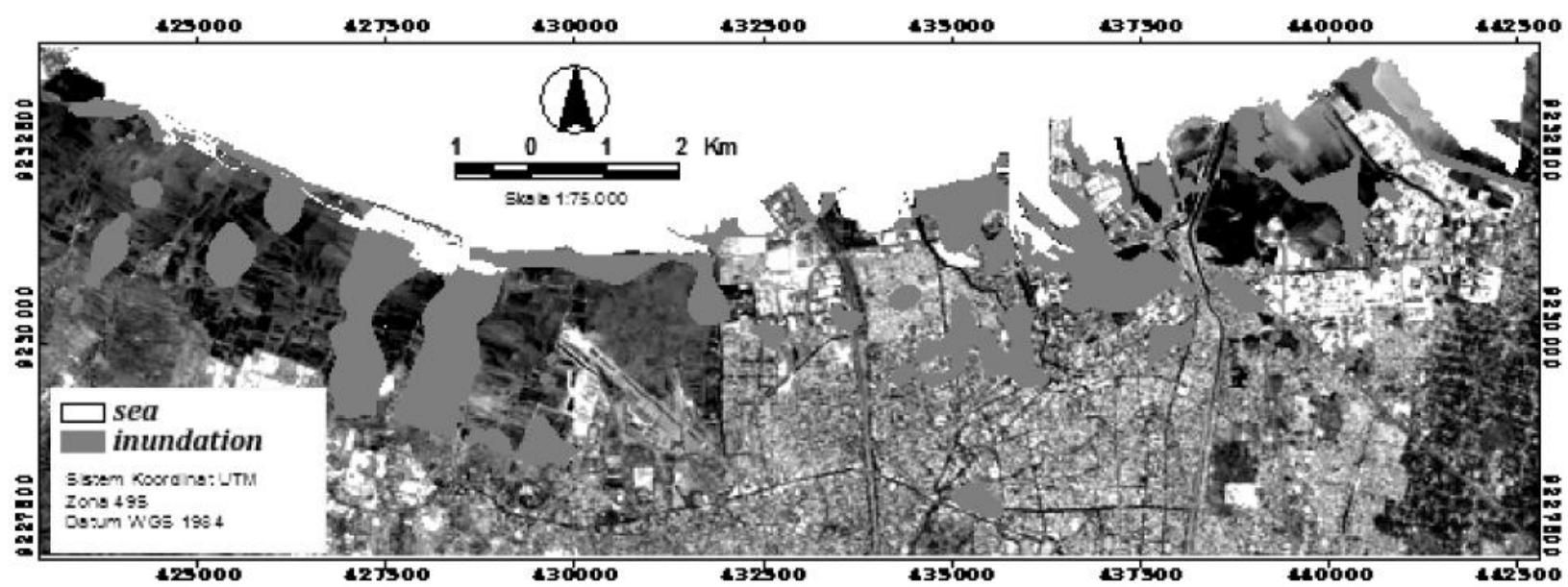

Figure 4. Distribution of inundation to optimistic scenario SLR 2030

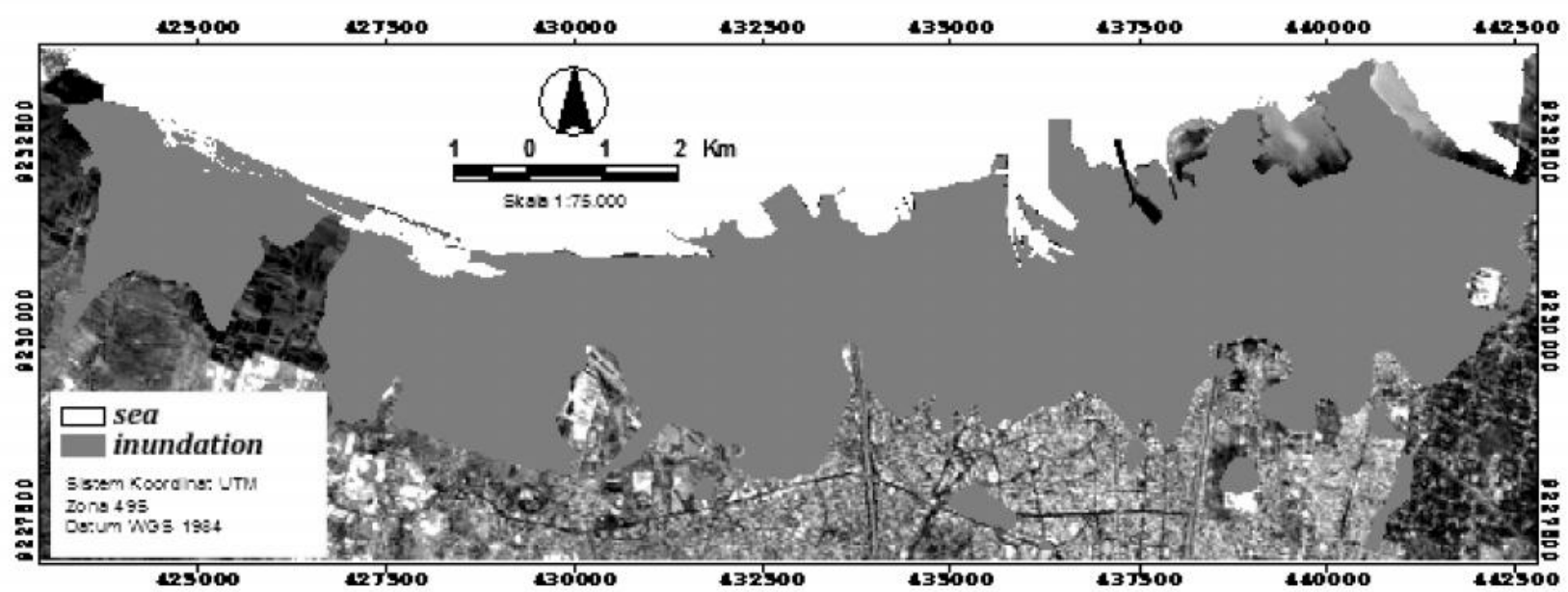

Figure 5. Pessimistic Subsidenceof SLR 2030

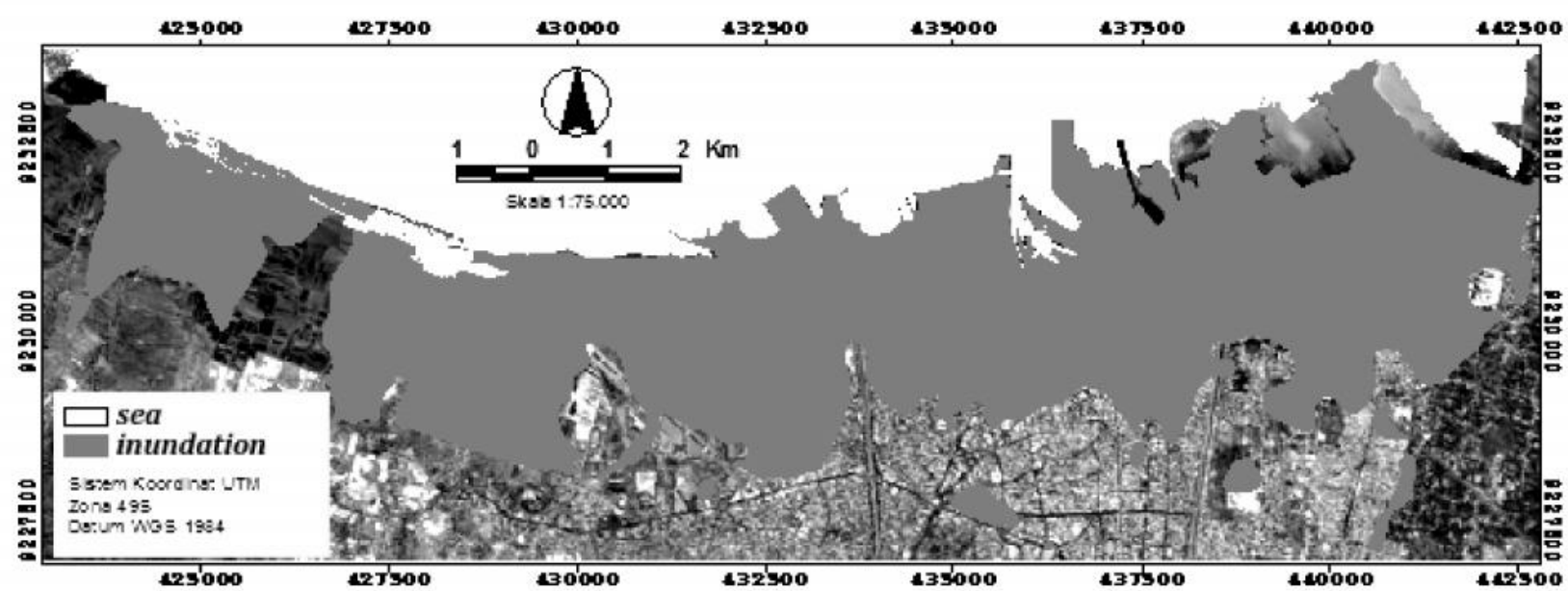

Figure 6. Pessimistic Subsidenceof SLR 2030

consideration in calculating the potential economic lossesdue tidal inundation and land subsidence.

The areas of inundation are classified into its utilization; therefore, the potential economic losses can be calculated due to the sea level rise on optimistic and pessimistic scenario in 2030. From Figure 5 and 6, we can also predict the sea level rise which is preceded by land subsidence.

Figure 7 shows that the Potential Economic Loss due to sea level rise reaches 28.0 trillion rupiahs on optimisticscenario and this number increases significantly to 28.72 trillion rupiahs on maximum 
scenario. This can be seen on the land subsidence scenario. The phenomenon of land subsidence gives a significant impact to the economic loss. The biggest economical loss is found in the land utilization of residential areas. This is because the economical value of residential areas is 10 times bigger than the economical value of other land utilizations. It is stated on minimum scenario that 18,157 units of building will be inundated suffering 4.97 trillion rupiahs and on maximum scenario is 26,516 units of building suffering
6.13 trillion rupiahs. Meanwhile, the second biggest loss is from the use of dikes with a significant increase from 0.66 trillion rupiahs on minimum scenario to 2.28 trillion rupiahs on maximum scenario.

\section{Conclusion}

Based on the research above, it is explained that the tidal inundation can cause some potential losses. The dynamic characteristic of an area, land subsidence,

Tabel 1. Areas of inundation and potential economic loss due to tidal inundation

\begin{tabular}{|c|c|c|c|c|c|c|}
\hline \multirow[b]{2}{*}{ Landuse } & \multirow[b]{2}{*}{2010} & \multirow[b]{2}{*}{$\begin{array}{c}\text { Potential } \\
\text { Loss(Million) }\end{array}$} & \multicolumn{4}{|c|}{2030} \\
\hline & & & Optimistic & $\begin{array}{l}\text { Potential } \\
\text { Loss } \\
\text { (Million) }\end{array}$ & Pessimistic & $\begin{array}{l}\text { Potential } \\
\text { Loss } \\
\text { (Million) }\end{array}$ \\
\hline Water body & 22.9 & 265.6 & 29,405 & 381.9 & 34.5 & 474.4 \\
\hline Airport & 0 & - & 0 & - & - & \\
\hline Shrub & 0.7 & 15.4 & 0.743 & 15.4 & 0.8 & 15.6 \\
\hline Dike & 684.9 & $556,119.20$ & 789,393 & $662,516.20$ & 913.6 & $781,528.10$ \\
\hline Building & 181 & $1,661,494.90$ & 207,559 & $2,164,221.10$ & 236.4 & $2,609,95.7$ \\
\hline Marshland & 3.1 & 31.8 & 3,198 & 46.5 & 3.3 & 57.9 \\
\hline Mixed Garden & 2.6 & 29.6 & 3,148 & 38.6 & 3.7 & 48.1 \\
\hline Bare land & 59.2 & 726.7 & 71,298 & 970 & 90 & $1,285.20$ \\
\hline $\begin{array}{l}\text { Residential Areas } \\
\text { Irrigated Rice }\end{array}$ & 209.7 & $1,484,738.50$ & 281,665 & $2,086,508.00$ & 356.4 & $2,671,712.60$ \\
\hline Field & 66.9 & $56,695.10$ & 72,075 & 60.298 .6 & 79.3 & 65.330 .9 \\
\hline Moor Land & 0 & 21.5 & 0.044 & 34.2 & 0 & 40.1 \\
\hline Amount & 1,231 & $3,760,138.30$ & $1,458.50$ & $4,975,030.50$ & $1,718.20$ & $6,130,388.60$ \\
\hline
\end{tabular}

Tabel 2. Areas of inundation and potential economic loss due to tidal inundation and land subsidence

\begin{tabular}{lrrrr}
\hline \multirow{2}{*}{ Landuse } & \multicolumn{4}{c}{ 2030 Land Subsidence } \\
\cline { 2 - 5 } & Optimistic & $\begin{array}{c}\text { Potential Loss } \\
\text { (Million) }\end{array}$ & Pessimistic & $\begin{array}{c}\text { Potential Loss } \\
\text { (Million) }\end{array}$ \\
\hline Water Body & 107,569 & $2,159.20$ & 111.1 & $2,202.20$ \\
Airport & 24,466 & $532,032.00$ & 29.4 & $637,472.60$ \\
Shrub & 1,077 & 22.4 & 1.1 & 22.4 \\
Dike & $2,104,297$ & $2,280,150.20$ & $2,163.20$ & $2,348,034.30$ \\
Building & 625,183 & $8,821,943.90$ & 628.3 & $8,879,626.30$ \\
Marshland & 4,217 & 87.6 & 4.2 & 87.6 \\
Mixed Garden & 67,475 & $1,120.80$ & 73.6 & $1,248.80$ \\
Bareland & 427,908 & $8,557.00$ & 433.7 & $8,684.90$ \\
Residential & 1424,78 & $16,234,922.30$ & $1,460.10$ & $16,630,015.90$ \\
Areas & 195,664 & $157,201.30$ & 210.8 & $171,466.90$ \\
Irrigated Rice & 53,114 & $42,912.20$ & 55.9 & $45,328.30$ \\
Field & $5,035.80$ & $28,081,108.80$ & $5,171.30$ & $28,724,190.20$ \\
Moor Land & & & & \\
\hline Amount & & & & \\
\hline
\end{tabular}




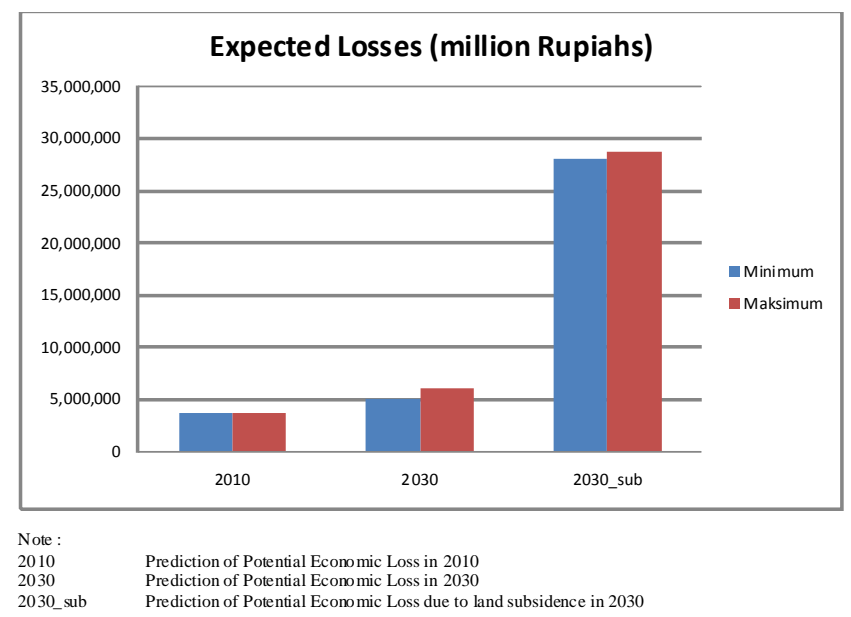

Figure 7. Potential Economic Loss due to inundation on minimum and maximum scenario in 2030

which happens every year withparticularlevel of intensity has an impact to the condition and distribution of tidal inundation in Semarang. This calculation can be a reference in determining the city development policies.

\section{References}

[IPCC] Intergovenrmental Panel on Climate Change (2007) Climate Change 2007: The Physical Science Basis Summary for Policy Makers. Contribution of Working Group I to the Fourth Assessment Report of the Intergovenrmental Panel on Climate Change. Paris: IPCC February 2007. http://www.aaas.org/news/ press_room/climate_change/media/4th_spm2feb07.pdf

Khasanah N, Lusiana B, Farida, Noordwijk M van (2004) Simulasi Limpasan Permukaan dan Kehilangan Tanah Pada Berbagai umur Kebun Kopi: Studi di Sumberjaya Lampung Barat. Agrivita. Vol. 26 (1):81-89.

Lubis, Joessair (2011) Peduli Lingkungan, Peduli Tata Ruang. Sumber: http://pustaka.pu.go.id/new/artikeldetail.asp?id=320

Marfai MA, King L (2008) Tidal inundation mapping under enhanced land subsidence in Semarang, Central Java Indonesia. Nat Hazard. Vol. 44 : 93-109 http://www.springerlink.com/ content/u02m33804127h626/

Suhelmi, IR (2011) Sistem Pendukung Keputusan Keruangan untuk Analisis Kerentanan Pesisir Akibat Kenaikan Muka Air Laut dan Amblesan Tanah di Semarang. Disertasi. Institut Pertanian Bogor. Bogor

Surminski Swenja, Ana Lopez, Joern Birkmann, Torsten Welle (2012)Current knowledge on relevant methodologies and data requirements as well as lessons learned and gaps identified at different levels, in assessing the risk of loss and damage associated with the adverse effects of climate change.UNFCCC expert meeting on assessing theriskof lossand damage associated with theadverseeffects of climate change Tokyo 24-26 March 2012.Sumber: http://unfccc.int/adaptation/cancun_adaptation_framework/ loss_and_damage/items/6597.php

Suroso, Susanto HA. 2006. Pengaruh Perubahan Tata Guna Lahan Terhadap Debit Banjir Daerah Aliran Sungai Banjaran. Jurnal Teknik Sipil, Vol. 3 (2):75-80. Universitas Pelita Harapan. http:// jurnalsipiluph.files.wordpress.com/2006/12/vol3-no2-naskah_3.pdf

Ward PJ, MA Marfai, F Yulianto,DR Hizbaron, JCJHAerts(2011)Coastal inundationanddamage exposure estimation: acasestudyforJakartaNatHazards(2011)56:899-916 DOI10.1007/s11069-010-9599-1

World Bank. (2009) Berinvestasi untuk Indonesia yang Lebih Berkelanjutan. Sumber: http://wwwwds.worldbank.org/external/default/WDSContentServer/WDSP/IB/2009/1 1/19/ 000333038_20091119000502/Rendered/PDF/507620v20Revis1box0info10CEA1bahasa.pdf 